\title{
Efficiency of Poultry Manure for Improving Nutrient Composition of Maize Plants under Calcareous Soil Environment
}

\author{
Muhammad Fiyyaz ${ }^{1}$, Ghulam Sarwar ${ }^{1 *}$, Noor-Us-Sabah ${ }^{1}$, Mukkram Ali Tahir ${ }^{1}$, Muhammad Aftab ${ }^{2}$, \\ Muhammad Zeeshan Manzoor ${ }^{1}$, Sher Muhammad ${ }^{3}$, Muhammad Latif ${ }^{4}$, Ayesha Zafar ${ }^{1}$, Imran Shehzad ${ }^{1}$, \\ Sarfraz Hussain ${ }^{5}$, Aneela Riaz ${ }^{6}$ and Abid Niaz ${ }^{2}$
}

${ }^{1}$ Deptartment of Soil and Environmental Sciences, College of Agriculture, University of Sargodha, Pakistan; ${ }^{2}$ Institute of Soil Chemistry and Environmental Sciences, AARI, Faisalabad, Pakistan; ${ }^{3}$ Department of Agricultural Sciences, Allama Iqbal Open University, Islamabad, Pakistan; ${ }^{4}$ ORIC, Allama Iqbal Open University, Islamabad, Pakistan; ${ }^{5}$ Institute of Soil Chemistry and Environmental Sciences, Kala Shah Kaku, Pakistan; ${ }^{6}$ Soil Bacteriology Section, AARI, Faisalabad, Pakistan.

Abstract | Deficiency of organic matter in Pakistani soils is well established fact. This deficiency of organic matter deteriorates soil physical properties and all related chemical processes in the soil. To overcome this issue, organic matter is added to these soils in so many forms like Farm Yard Manure (FYM), compost, green manure, rice husk and poultry manure. All these practices are favoured to enhance soil productivity level. Keeping in view the current scenario of country, this experiment was conducted. Experiment contained 11 treatments applied under completely randomized design (CRD) included, $\mathrm{T} 1=$ chemical fertilizers at recommended rate, $\mathrm{T} 2=$ chemical fertilizers at half recommended rate, $\mathrm{T} 3=$ poultry dung at the rate of $5 \mathrm{t}$ $\mathrm{ha}^{-1}, \mathrm{~T} 4=$ poultry dung at the rate of $7.5 \mathrm{t} \mathrm{ha}^{-1}, \mathrm{~T} 5=$ poultry dung at the rate of $10 \mathrm{tha} \mathrm{h}^{-1}, \mathrm{~T} 6=\mathrm{T} 1+\mathrm{T} 3, \mathrm{~T} 7$ $=\mathrm{T} 1+\mathrm{T} 4, \mathrm{~T} 8=\mathrm{T} 1+\mathrm{T} 5, \mathrm{~T} 9=\mathrm{T} 2+\mathrm{T} 3, \mathrm{~T} 10=\mathrm{T} 2+\mathrm{T} 4$ and $\mathrm{T} 11=\mathrm{T} 2+\mathrm{T} 5$. Maize was grown as test crop to evaluate efficiency of these treatments. At maturity, plant samples of maize were collected from all pots. Laboratory analysis for collected plant samples was carried out. Data were statistically analyzed. Results indicated that treatment (T8) produce maximum nitrogen $(3.27 \%)$, phosphorus (1.0\%) and potassium $(2.85 \%)$ concentration in shoots of maize plants. The same trend of improvement was noted for maximum nitrogen $(3.16 \%)$, phosphorus $(0.92 \%)$ and potassium $(2.88 \%)$ concentration in roots of maize plants.

Received | March 24, 2021; Accepted | April 26, 2021; Published | June 19, 2021

*Correspondence | Ghulam Sarwar, Department of Soil and Environmental Sciences, College of Agriculture, University of Sargodha, Pakistan; Email: ghulam.sarwar@uos.edu.pk

Citation | Fiyyaz, M., G. Sarwar, N.U. Sabah, M.A. Tahir, M. Aftab, M.Z. Manzoor, S. Muhammad, M. Latif, A. Zafar, I. Shehzad, S. Hussain, A. Riaz and A. Niaz. 2021. Efficiency of poultry manure for improving nutrient composition of maize plants under calcareous soil environment. Pakistan Journal of Agricultural Research, 34(3): 473-478.

DOI | https://dx.doi.org/10.17582/journal.pjar/2021/34.3.473.478

Keywords | Maize shoots, Maize roots, Poultry manure, Mineral fertilizer, Nutrient concentration

\section{Introduction}

$\mathrm{M}$ aize is cross-pollinated specie and monoecious crop of Asia. Maize is regarded as $3^{\text {rd }}$ most important crop after rice and wheat in Pakistan. It is grown for multipurpose throughout the globe. It is grown for oil, grains and fodder purpose in the country. It plays a significant role in the economy of the country. Maize contributed $0.4 \%$ of GDP and $2.1 \%$ of total profits of national agriculture (Shah et al., 2014). About $99 \%$ of maize is mainly grown in Punjab and KPK provinces (Rehman et al., 2015). In Pakistan, production of maize was about 7000 thousand tons in year 2020 (GOP, 2020). Production of maize was 36581000 tons from 9 lac 81 thousand ha in 2010 in the country. Maize grains are rich 
source of minerals, vitamins and ashes. Maize grains have fats $(5.8 \%)$, proteins $(10 \%)$, starch $(72 \%)$, sugar (3\%) and burning ash (1.7\%). These are used for the manufacture of cosmetics, flakes, syrup, alcohol, starch and fats (Chaudhary et al., 2014).

Maize is very beneficial fodder and is the major source of livestock forage in all over Pakistan. It is reaped after 8-10 weeks after sowing (Rashid and Iqbal, 2012). Maize has important role for the manufacture of value-added foods like jellies, glucose, flakes, and custard in several businesses. Now a days, it is also used in making of varnishes, ammunition, paints shortening compounds, soaps and many other products. Maize fodder contains $51.69 \%$ neutral detergent fiber, $40.18 \%$ crude fiber, 28.797 $\%$ cellulose, $22.98 \%$ acid detergent fiber, $10.35 \%$ crude protein, and $9.09 \%$ moisture whereas maize seed grains contain $71.97 \%$ starch, $4.85 \%$ oil, $9.74 \%$ protein, and $9.44 \%$ crude fiber (Ali et al., 2014).

Inadequate management practices and insufficient as well as unbalanced fertilizer application is degrading soils continuously in Pakistan. Deficiency or organic matter is also one factor of this degradation. Quantity of organic matter is less than $1.0 \%$ in country soils that affects plant growth and efficiency. Status of nutrients in the soil determines plant response to added fertilizers. Addition of unbalanced and improper fertilizer may cause environmental pollution $(\mathrm{Oad}$ et al., 2004; Prabhu et al., 2003). Organic manure enhances soil fertility and increase plant growth as a supplement of manures due to production of various nutrient and chelating effect on cations by normal acids (Mohanty et al., 2006).

Growth and yield of rice-wheat plants was improved with the addition of different organic amendments (compost, FYM, sesbania green manure). Usage of compost proved superior to all others. This positive trend in plant growth and development was further strengthened when chemical fertilizer was coupled with these organic amendments (Sarwar, 2005). Likewise, combination of compost + chemical fertilizers produced supreme agglomeration in rice-wheat plants compared to FYM and Sesbania. Using FYM proved to be superior to control and led to a significant rise in the number of ricewheat crop growers. An evaluation of compost and fertilizer evidenced the advantage of compost over chemical fertilizer in this respect, but mixture of these demonstrated to be more effective than using compost alone (Sarwar et al., 2007).

Collective usage of carbon-based manures like cow dung, poultry manure, residues of harvested crops and green manure crops with mineral fertilizer is the best way to manage nutrients in soil (Antil, 2012). This strategy leads to restore soil fertility, conserve soil and decrease environmental pollution. Extensive usage of various nutritious sources demonstrated imperative for more demand of crop growth and sustainable agriculture (Korsaeth et al., 2002). A rise in rice and wheat growth was observed when mineral fertilizers was used with various sources of organic materials (Sarwar et al., 2020).

\section{Materials and Methods}

This trail was carried out in pots to evaluate efficiency of mineral fertilizer and poultry manure on nutrient composition of maize plants. Samples of soil were taken for determination of various laboratory parameters before starting experiment (Table 1). After analysis, pots were filled with ten (10) $\mathrm{kg}$ soil and irrigated by ground water. Completely randomized design was applied to arrange the pots. Current experiment included 11 treatments and 3 replications. Various treatments included $\mathrm{T} 1=$ chemical fertilizers at recommended rate, $\mathrm{T} 2=$ chemical fertilizers at half recommended rate, $\mathrm{T} 3=$ poultry dung at the rate of 5 t ha ${ }^{-1}, \mathrm{~T} 4=$ poultry dung at the rate of $7.5 \mathrm{tha}^{-1}, \mathrm{~T} 5=$ poultry dung at the rate of $10 \mathrm{tha}^{-1}, \mathrm{~T} 6=\mathrm{T} 1+\mathrm{T} 3$, $\mathrm{T} 7=\mathrm{T} 1+\mathrm{T} 4, \mathrm{~T} 8=\mathrm{T} 1+\mathrm{T} 5, \mathrm{~T} 9=\mathrm{T} 2+\mathrm{T} 3, \mathrm{~T} 10=\mathrm{T} 2+$ $\mathrm{T} 4$ and $\mathrm{T} 11=\mathrm{T} 2+\mathrm{T} 5$.

Table 1: Soil Characteristics used in experiments.

$\begin{array}{lll}\text { Characteristics } & \text { Unit } & \text { Value } \\ \text { Saturation percentage } & \% & \\ \mathrm{pH}_{\mathrm{s}} & - & 7.50 \\ \mathrm{EC} & \mathrm{dS} \mathrm{m} e^{-1} & 1.78 \\ \mathrm{CO}_{3} & \mathrm{me} \mathrm{L}^{-1} & 3.60 \\ \mathrm{HCO}_{3} & \mathrm{me} \mathrm{L}^{-1} & 6.30 \\ \mathrm{Cl} & \mathrm{me} \mathrm{L}^{-1} & 4.10 \\ \mathrm{SO}_{4} & \mathrm{me} \mathrm{L}^{-1} & 3.80 \\ \mathrm{Ca}+\mathrm{Mg} & \mathrm{me} \mathrm{L}^{-1} & 4.50 \\ \mathrm{Na} & \mathrm{me} \mathrm{L}^{-1} & 10.8 \\ \mathrm{SAR} & - & 7.20 \\ \mathrm{Sand} & \% & 45.1 \\ \text { Silt } & \% & 26.8 \\ \text { Clay } & \% & 28.1 \\ \text { Textural class } & - & \text { Sandy clay loam }\end{array}$

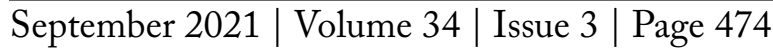


Maize variety (FM3) was sown in all the pots. Poultry manure (PM) was applied according to treatments. Initially five seeds were sown per pot and after germination three plants were maintained. Urea, SSP and potassium sulfate were applied as sources for NPK. Recommended rate of NPK used in this study was $\mathrm{N}=225, \mathrm{P}_{2} \mathrm{O}_{5}=100$ and $\mathrm{K}_{2} \mathrm{O}=100 \mathrm{~kg} \mathrm{ha}^{-1}$ respectively. Crop was harvested at maturity. Plant samples were collected from all pots and analysis was done by for each sample.

\section{Analytical methods for soil analysis}

Analytical methods for laboratory determinations were used as given in Hand Book No. 60 of USDA (1969).

\section{Soil organic matter}

For organic matter determination method 24 was used.

\section{Available phosphorus}

It was determined by Olsen's method (Tandon, 2001).

\section{Soluble potassium}

Soluble potassium was determined by (Method 11a).

\section{Digestion of plant samples for the determination of $K, N$ and $P$ contents}

Plant samples of $0.5 \mathrm{~g}$ were transferred into digestion vessel. A volume of $10 \mathrm{ml}$ of diacid mixture $\left(\mathrm{HNO}_{3}\right.$ : $\mathrm{HClO}_{4}=2: 1$ ) was taken into the vessel and kept for overnight. Samples were digested next day on hot plate at $250^{\circ} \mathrm{C}$ till material became transparent. After it, samples were filtered with Whatman filter paper No. 40 and all the samples were stored in plastic bottles.

\section{Potassium (K), phosphorous (P) and nitrogen (N) determination}

$\mathrm{K}$ from digested plant samples were determined through flame photometer while $\mathrm{P}$ was determined using colorimetric method with spectrophotometer. Nitrogen (N) was determined using Kjeldahl method.

\section{Statistical analysis}

Statistics 8.1 software was used for the statistical analysis. Analysis of Variance (ANOVA) was made for different parameters (Steel et al., 1997).

\section{Results and Discussion}

Nitrogen in shoots of maize plants

An integral part of plant tissue is nitrogen. Impact of combined application of chemical fertilizers and PM substantially upgraded the $\mathrm{N}$ concentration of maize plant (Figure 1). It was noticed that treatment T8 (receiving full dosage of mineral fertilizer along with $10 \mathrm{t} \mathrm{ha}^{-1}$ of $\mathrm{PM}$ ) resulted in highest nitrogen concentration of maize shoot with value of $3.27 \%$. Treatment T7 found next in this regard showing value of $3.08 \% \mathrm{~N}$ in maize shoot. Conversely, lowest $\mathrm{N}$ percentage was found in $\mathrm{T} 2$ receiving half dosage of mineral source of nitrogen. The numerical value for T2 was $0.99 \%$. It was apparent from the data that treatments receiving combined sources of nutrition performed better than their sole use. Results of many earlier researchers favored these outcomes that combined use of mineral and organic nutritional sources upgraded the mineral composition of maize plant parts (Sial et al., 2000; Bokhtiar and Sakurai, 2005).

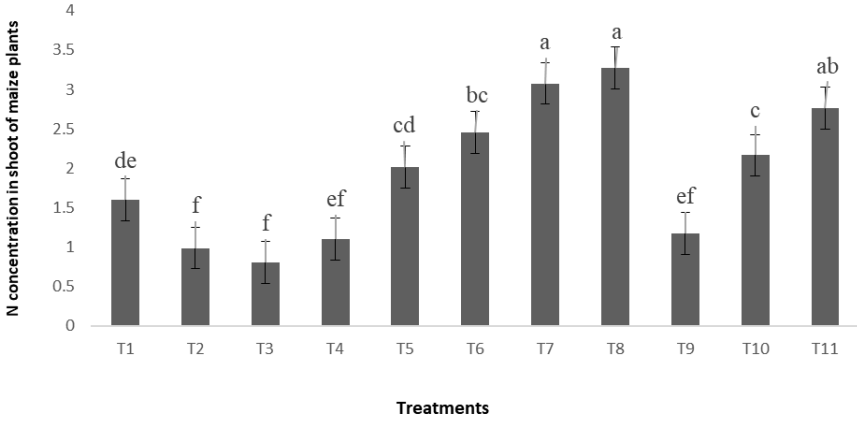

Figure 1: Nitrogen concentration in shoot of maize plants (\%).

\section{Phosphorus in shoots of maize plants}

Data related to $\mathrm{P} \%$ of maize shoot was plotted in Figure 2. It was reflected that $\mathrm{P} \%$ was positively improved by combined application of mineral (fertilizer) and organic (PM) sources of nutrients in maize. Again, T2 receiving half recommended dosage of mineral fertilizers proved inferior among all treatments by resulting in lowest concentration of $\mathrm{P}(0.14 \%)$ in maize shoot. However, T8 (receiving full dosage of mineral fertilizer along with $10 \mathrm{tha}^{-1}$ of $\mathrm{PM}$ ) proved superior in this regard by resulting in highest concentration of $\mathrm{P}$ in maize shoot with value of $1 \%$ followed by T11 (receiving half dosage of mineral fertilizer along with $10 \mathrm{t} \mathrm{ha}^{-1}$ of PM) having value of $0.88 \%$ P. Hence proved, that application of PM in combination with mineral nutritional source was better in terms of improving $\mathrm{P} \%$ of maize plant. These conclusions are supported by many researchers (Oad et al., 2004; Ahmad et al., 2007). 


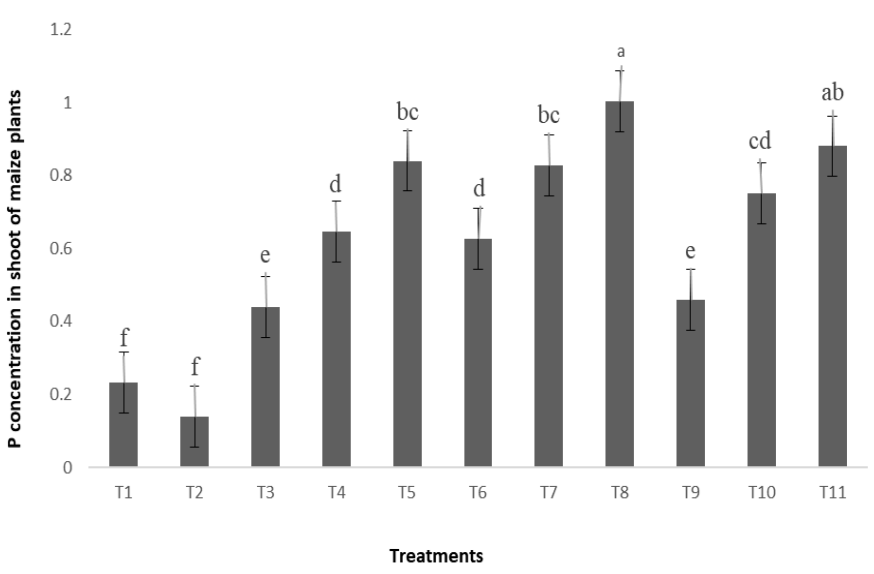

Figure 2: Phosphorus concentration in shoot of maize plants (\%).

\section{Potassium in shoots of maize plants}

Efficacy of collective application of chemical fertilizers and PM substantially upon $\mathrm{K}$ concentration of maize plant was plotted in Figure 3. Results suggested that lowest $\mathrm{K}$ concentration of maize shoot was noticed in T2 (receiving recommended dosage of mineral fertilizer) showing value of $1.84 \%$ that was approached to the highest value $2.85 \%$ of in $\mathrm{T} 8$ receiving full dosage of mineral fertilizer along with $10 \mathrm{t} \mathrm{ha}^{-1}$ of PM. Treatment T11 (receiving half dosage of mineral) found next in this regard showing value of $2.76 \% \mathrm{~K}$ in maize shoot. It was apparent from the data that treatments receiving combined sources of nutrition performed better than their sole use. Outcomes of many earlier researchers also suggested similar findings that combined use of mineral and organic nutritional sources upgraded the mineral composition of maize plant parts (Sial et al., 2000; Bokhtiar and Sakurai, 2005).

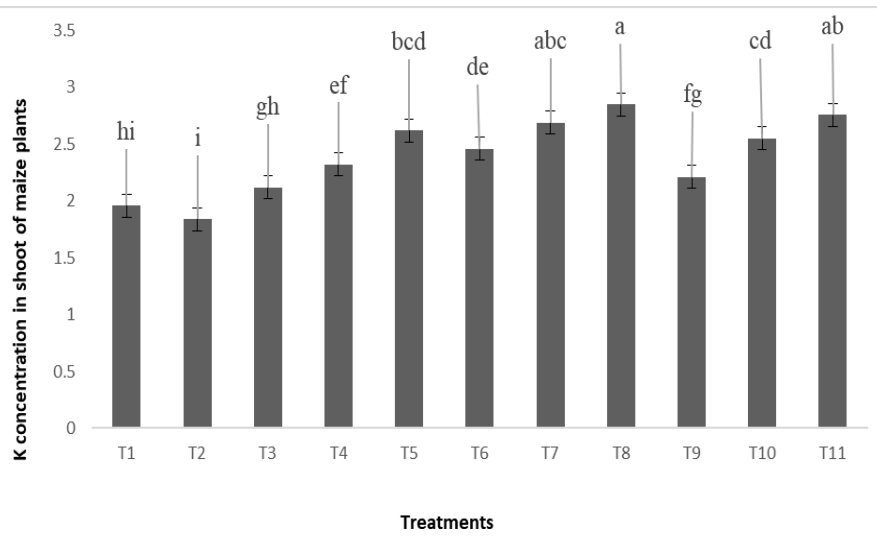

Figure 3: Potassium concentration in shoot of maize plants (\%).

\section{Nitrogen in roots of maize plants}

Collective application of chemical fertilizers and PM substantially upgraded the $\mathrm{N}$ concentration of maize plant roots. It was evident from Figure 4 that treatment T8 (receiving full dosage of mineral fertilizer along with $10 \mathrm{t} \mathrm{ha}^{-1}$ of PM) resulted in highest nitrogen concentration of maize root with value of $3.16 \%$. Treatment T7 found next in this regard showing value of $2.99 \% \mathrm{~N}$ in maize root. On the other hand, lowest $\mathrm{N}$ percentage was found in $\mathrm{T} 2$ receiving half dosage of mineral source of nitrogen. The numerical value for T3 (receiving PM @ $5 \mathrm{t} \mathrm{ha}^{-1}$ ) was $0.73 \%$. It was apparent from the data that treatments receiving combined sources of nutrition performed better than their sole use. Results of many earlier researchers favored these outcomes that combined use of mineral and organic nutritional sources upgraded the mineral composition of maize plant parts (Sial et al., 2000; Bokhtiar and Sakurai, 2005). Similarly, Zhang et al. (2000) and Shah et al. (2007) also documented similar outcomes regarding betterment of mineral composition of maize plant parts upon addition of organic carbon rich sources of nutrition like PM.

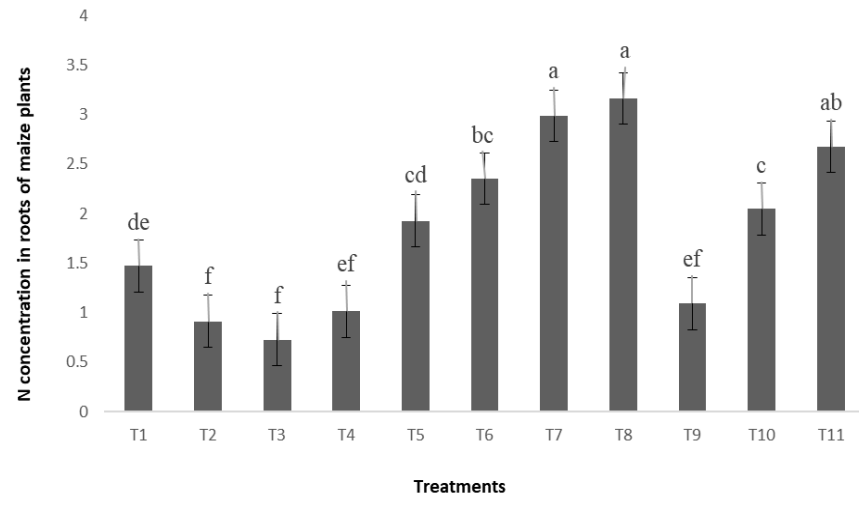

Figure 4: Nitrogen concentration in roots of maize plants (\%).

\section{Phosphorus in roots of maize plants}

Data with respect to $\mathrm{P} \%$ of maize root was plotted in Figure 5. It was reflected that $\mathrm{P} \%$ of maize root was positively improved by combined application of mineral (fertilizer) and organic (PM) sources of nutrients. Again, T2 (receiving half dosage of mineral fertilizers) proved inferior among all treatments by resulting in lowest concentration of $\mathrm{P}(0.13 \%)$ in maize shoot. However, T8 (receiving full dosage of mineral fertilizer along with $10 \mathrm{t} \mathrm{ha}^{-1}$ of $\mathrm{PM}$ ) proved superior in this regard by resulting in highest concentration of $\mathrm{P}$ in maize root with value of $0.92 \%$ followed by $\mathrm{T} 11$ (receiving half dosage of mineral fertilizer along with $10 \mathrm{t} \mathrm{ha}^{-1}$ of PM) having value of $0.83 \% \mathrm{P}$. Hence proved, that application of PM in combination with mineral nutritional source was better in terms of improving $\mathrm{P} \%$ of maize plant. These conclusions are supported by many researchers (Oad et al., 2004; Ahmad et al., 2007; Ribeiro et al., 2007). 


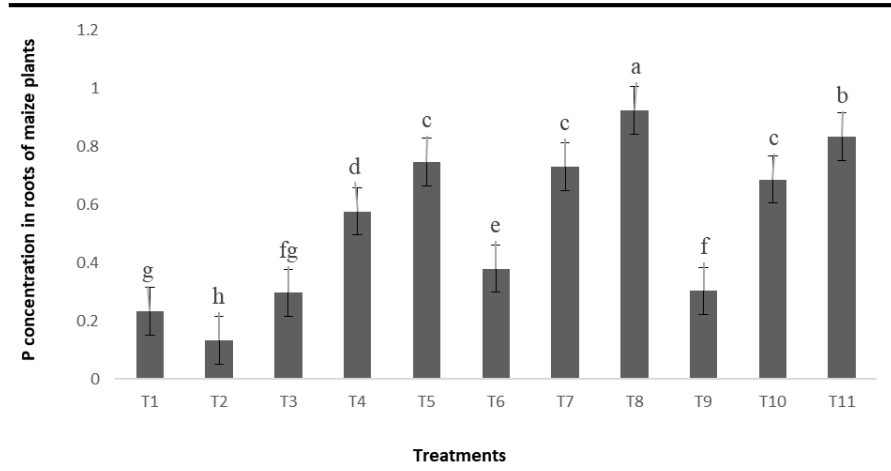

Figure 5: Phosphorus concentration in roots of maize plants (\%).

\section{Potassium in roots of maize plants}

Role of collective application of chemical fertilizers and PM substantially upon $\mathrm{K}$ concentration of maize plant roots was plotted in Figure 6. It was noticed that lowest $\mathrm{K}$ concentration of maize root was found in $\mathrm{T} 2$ (receiving half dosage of mineral fertilizer) showing value of $1.86 \%$ that was approached to the highest value $2.88 \%$ of in $\mathrm{T} 8$ receiving full dosage of mineral fertilizer along with $10 \mathrm{t} \mathrm{ha}^{-1}$ of PM. Treatment T11 (receiving half dosage of mineral) ranked next in this regard showing value of $2.78 \% \mathrm{~K}$ in maize shoot. It was apparent from the data that treatments receiving combined sources of nutrition performed better than their sole use. Outcomes of many earlier researchers also suggested similar findings that combined use of mineral and organic nutritional sources upgraded the mineral composition of maize plant parts (Sial et al., 2000; Bokhtiar and Sakurai, 2005; Ayeni and Adetunji, 2010).

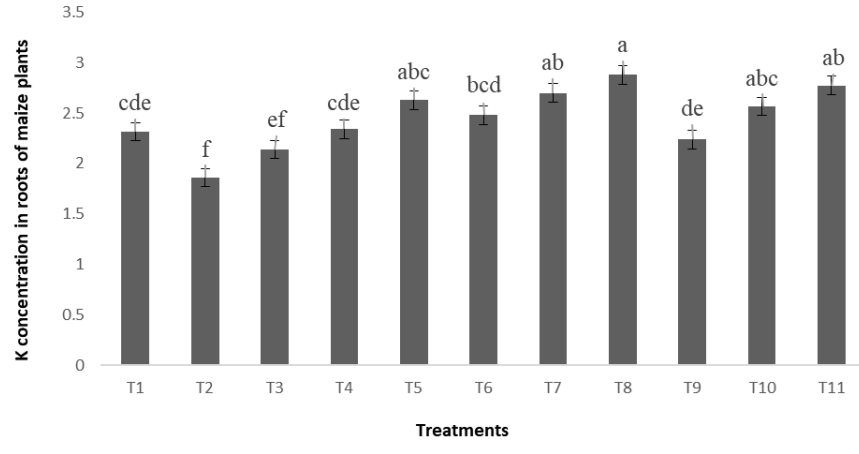

Figure 6: Potassium concentration in roots of maize plants (\%).

\section{Conclusions and Recommendations}

It was concluded that integrated usage of full dosage of chemical fertilizers + poultry dung at the rate of $10 \mathrm{t} \mathrm{ha}^{-1}$ proved superior treatment to all others for improving concentration of nitrogen, phosphorus and potassium in shoots as well as roots of maize plants. Therefore, it is suggested to farmers that they should use mineral fertilizer coupling with poultry dung to get nutrient enriched fodder of maize.

\section{Novelty Statement}

Usage of poultry dung enriched $\mathrm{N}, \mathrm{P}$ and $\mathrm{K}$ concentration in shoot and roots of maize plants.

\section{Author's Contribution}

Muhammad Fiyyaz: Performed the research.

Ghulam Sarwar: Supervised the experiment.

Noor-us-Sabah: Assisted the conduction of experiment.

Mukkram Ali Tahir: Co-supervised the experiment. Muhammad Aftab and Sarfraz Hussain: Collected the data and presented graphically.

Sher Muhammad and Muhammad Latif: Analyzed data statistically.

Muhammad Zeeshan Manzoor and Ayesha Zafar: Laboratory analysis of said parameters.

Imran Shehzad, Aneela Riaz and Abid Niaz: Assisted in write up and final editing of manuscript.

\section{Conflict of interest}

The authors have declared no conflict of interest.

\section{References}

Ahmad, M., R. Ahmad and A. Rehman. 2007. Crowding stress tolerance in maize hybrids. Economic and Business Review, the Daily Dawn, Lahore, Pakistan. October 17- 22. pp. 3. Ali,Y.,Z.Aslam,M.Y.Ashraf and G.R.Tahir.2014. Effect of salinity on chlorophyll concentration, leaf area, yield and yield components of rice genotypes grown under saline environment. Int. J. Environ. Sci. Technol., 1(3): 221-225. https://doi.org/10.1007/BF03325836

Antil, R.S., 2012. Integrated plant nutrient supply for sustainable soil health and crop productivity. A. Kumar (Eds) vol. 3. Focus Global Reporter, 2012.

Ayeni, L. and M. Adetunji. 2010. Integrated application of poultry manure and mineral fertilizer on soil chemical properties, nutrient uptake, and yield and growth components of maize. Nat. Sci., 8(1): 60-67.

Bokhtiar, S.M. and K. Sakurai. 2005. Integrated use of organic manure and chemical fertilizer on growth, yield and quality of sugarcane in high Ganges river flood plain soils of Bangladesh. 
Commun. Soil Sci. Plant Anal., 36: 1823-1837. https://doi.org/10.1081/CSS-200062460

Chaudhary, D.P., S. Kumar and S. Langyan. 2014. Maize: Nutrition dynamics and novel uses. Springer New Delhi, Heidelberg, New York, Dordrecht, London. https://doi. org/10.1007/978-81-322-1623-0

GoP, 2020. Pakistan Economic Survey, 2019-20. Agricultural Statistics of Pakistan. Government of Pakistan, Ministry of Food, Agriculture and Livestock (Economic Wing), Islamabad.

Korsaeth, A., T.M. Henriksen and L.R. Bakken. 2002. Temporal changes in mineralization and immobilization of $\mathrm{N}$ during degradation of plant material: Implications for the plant $\mathrm{N}$ supply and $\mathrm{N}$ losses. Soil Biol. Biochem., 34: 789-799. https://doi.org/10.1016/S00380717(02)00008-1

Mohanty, S., N.K. Paikaray and A.R. Rajan. 2006. Availability and uptake of phosphorus from organic manures in groundnut (Arachis bypogea L.) corn (Zea mays L.) sequence using radio tracer technique. Geoderma, 133(3): 225-230. https:// doi.org/10.1016/j.geoderma.2005.07.009

Oad, F.C., U.A. Buriro and S.K. Agha. 2004. Effect of organic and inorganic fertilizer application on maize fodder production. Asian J. Plant Sci., 3: 375-377. https://doi.org/10.3923/ ajps.2004.375.377

Prabhu, T., P. Narwadekar, A. Sannindranath and M. Rofi. 2003. Effect of integrated nutrient management on growth and yield of okra (Abelmoschus esculentus (L.) Moench) cv. Parbhani Kranti. Orissa J. Hortic., 31(1): 17-21.

Rashid,M.and M.Iqbal.2012.Effect of phosphorus fertilizer on the yield and quality of maize ( $Z e a$ mays $\mathrm{L}$ ) fodder on clay loam soil. J. Anim. Plant Sci., 22(1): 199-203.

Rehman, A., L. Jingdong, B. Shahzad, A.A. Chandio, I. Hussain, G. Nabi and M.S. Iqbal. 2015. Economic perspectives of major field crops of Pakistan: An empirical study. Pac. Sci. Rev. B Human. Soc. Sci., 1(3): 145-158. https:// doi.org/10.1016/j.psrb.2016.09.002

Ribeiro, H.M., A.M. Romero, H. Pereira, P. Borges, F. Cabral and E. Vasconcelos. 2007. Evaluation of a compost obtained from forestry wastes and solid phase of pig slurry as a substrate for seedlings production. Biol. Resour. Technol., 98: 3294-3297. https://doi.org/10.1016/j. biortech.2006.07.002

Sarwar, G., 2005. Use of compost for crop production in Pakistan. Okologie und Umweltsicherung. 26/2005. Universität Kassel, Fachgebiet Landschaftsökologie und Naturschutz, Witzenhausen, Germany.

Sarwar, G., M.A. Malik, N-S. Sabah, M.A. Tahir, M. Aftab, M.Z. Manzoor and A. Zafar. 2020. Comparative efficiency of compost, farmyard manure and sesbania green manure to produce rice-wheat crops under salt stressed environmental conditions. J. Pure Appl. Agric., 5(3): 33-42.

Sarwar, G., N. Hussain, H. Schmeisky and S. Muhammad. 2007. Use of compost an environment friendly technology for enhancing rice-wheat production in Pakistan. Pak. J. Bot., 39(5): 1553-1558.

Shah, H., M.A. Khan, N. Akmal and W. Akhtar. 2014. Assessment of the maize situation, outlook and investment opportunities to ensure food security in Pakistan. MAIZE-CRP Project Report. Soc. Sci. Res. Inst., NARC, Pakistan.

Shah, Z., Z. Shah, M. Tariq and M. Afzal. 2007. Response of maize to integrated use of compost and urea fertilizers. Sarhad J. Agric., 23(3): 667673.

Sial, M.A., M.A. Arian and M. Ahmad. 2000. Genotype $\mathrm{x}$ environment interaction on bread wheat grown over multiple sites and years in Pakistan. Pak. J. Bot., 32(1): 85- 91.

Steel, R.G.D., J.H. Torrie and D.A. Dicky. 1997. Principles and procedures of statistics: A biometrical approach. 3rd ed. McGraw-Hill Book Int. Co., Singapore.

Tandon, H.L.S., 2001. Methods of analysis of soils, plants, waters and fertilisers. Fertiliser Development and Consultation Organisation 204-204A Bhanot Corner, 1-2 Pamposh Enclave New Delhi-110048, India.

U.S. Salinity Laboratory Staff, 1969. Diagnosis and Improvements of saline and alkali soils. Handbook No. 60. USDA. U.S. Govt. Printing Office, Washington, DC, USA.

Zhang,M.,M.Nyborg, S.S.Malhi and E.D. Solberg. 2000. Localized root growth in soil induced by controlled-release urea granule and barley nitrogen uptake. J. Plant Nutr., 23(3): 413-422. https://doi.org/10.1080/01904160009382027 